\title{
A CONSCIÊNCIA E A QUESTÃO DA HUMANIDADE DO HUMANO EM DAS WESEN DES CHRISTENTUMS, DE LUDWIG FEUERBACH
}

\author{
Nuno Castanheira \\ Mestrando da Universidade de Lisboa
}

\section{Introdução}

\section{Transcendência na imanência - breve abordagem metodológica}

Na obra "Qu'est-ce qu'une vie réussie?"', Luc Ferry procura reflectir acerca da pertinência e do lugar de um questionamento acerca da 'vida boa' nas presentes sociedades democráticas, descendentes directas da divisa 'pensar por si mesmo'; esta divisa, saída das reflexões cartesianas, foi posteriormente aprofundada por diversas perspectivas filosóficas, permanecendo o cerne de diversas investigações em filosofia até aos nossos dias. Como resultante do esforço reflexivo iniciado no séc. XVII - e mais como uma sua deturpação ou efeito deletério do que como uma consequência directa das intenções dos seus protagonistas - surgiu como marca do universo hodierno um individualismo sustentado por uma imanência radical ao real e caracterizado pelo fechamento a qualquer tipo de valores com origem exterior ao exercício da liberdade individual, sejam estes emanados por transcendências cosmológicas, onto-teológicas, ou de qualquer outro tipo.

Do ponto de vista de Luc Ferry, a recusa da transcendência tout court revela um duplo paradoxo, assente numa compreensão da transcendência como dom e numa concepção da fé como adesão aos valores por aquela emanados, adesão resultante de uma escolha livre, autonómica ainda que sempre reenviando a uma dependência radical, a uma heteronomia originária - e já não como submissão pura e simples a uma heteronomia autoritária e indisputada. Este terceiro tipo de transcendência, uma

${ }^{1}$ Luc Ferry, Qu'est-ce qu'une vie réussie?, Éditions Grasset \& Fasquelle, Paris, 2002. 
transcendência na imanência, de natureza duplamente paradoxal - porque marcada, por um lado, por uma heteronomia radical que não exclui a autonomia da escolha religiosa e, por outro, por um ideal de autonomia que não apaga a realidade multiforme da heteronomia - remete para a compreensão daquilo que este autor apelida de humanismo do homem-deus, um tipo de transcendência dos valores surgida na imanência da vida e do exercício do livre arbítrio humano e que se dá como horizonte de sentido desse mesmo exercício ${ }^{2}$. Na base deste humanismo reside uma compreensão da transcendência na imanência da consciência e da liberdade humana não como fundamento, como movimento de identificação e de anulação de si mesmo, mas como actividade de descoberta e abertura a uma doação que, vinda de fora e sempre infundada, se dá ético-esteticamente como horizonte de sentido do exercício do arbítrio humano.

Ao longo do texto que aqui apresentamos procuraremos mostrar que é justamente num ponto de vista semelhante, embora cerca de um século antes, que se coloca Ludwig Feuerbach e a sua filosofia da revelação, tal como é exposta no seu escrito de 1841 , Das Wesen des Christentums ${ }^{3}$. A posição que assumiremos, que orientará e que será justificada com todo o desenvolvimento deste texto, terá como eixo uma hermenêutica fenomenológica, uma interpretação fundada numa descrição e numa análise cuidadas de alguns momentos determinantes para a compreensão da obra aqui em questão. No entanto, abordará também o próprio texto de Feuerbach que iremos analisar como sendo ele mesmo uma obra de fenomenologia, ou ainda, se quisermos utilizar os termos do seu autor e ser mais fiéis à linguagem da época - da qual a actual fenomenologia é descendente directa -, de genético-crítica ${ }^{4}$, entendida como uma analítica dos elementos que se encontram na génese da religiosidade humana e a sua significação como movimento de religação do homem com uma transcendência que é a sua própria humanidade, dada na imanência da sua vida de consciência.

\section{O significado da Revelação em Das Wesen des Christentums}

As reflexões de Feuerbach no campo acima descrito estão inseridas, de acordo com as suas próprias palavras, numa filosofia ou pensar da revelação:

${ }^{2}$ Cf. Luc Ferry, Qu'est-ce qu'une vie réussie?, 2002, pp. 501-502

${ }^{3}$ Ludwig Feuerbach, Das Wesen des Christentums, trad. portuguesa de Adriana Veríssimo Serrão, Fundação Calouste Gulbenkian, Lisboa, 1994 (daqui em diante indicado apenas por Das Wesen des Christentums, referindo-se toda a paginação à versão portuguesa).

${ }^{4}$ Das Wesen des Christentums, p. 36. 
A presente obra contém os elementos - note-se bem - apenas os elementos críticos para uma filosofia da religião positiva ou da revelação (Offenbarung) $[\ldots] .^{5}$

Deste modo, é necessário que comecemos por colocar uma questão com dois momentos distintos, mas co-implicados, a saber: num primeiro momento, o que devemos entender por revelação (Offenbarung) ${ }^{6}$; e, num segundo momento, porquê uma tal denominação? A resposta à primeira parte da questão implicará a justificação para a segunda parte.

$\mathrm{Na}$ língua portuguesa, o verbo revelar significa descobrir, desocultar, manifestar, declarar, expor. Numa leitura mais demorada, este termo resulta de uma composição entre o prefixo re e o verbo velar. O prefixo $r e$ é designativo de repetição, de um tornar a dizer ou fazer algo. No que diz respeito ao verbo aí presente, velar, observamos que encerra uma dupla significação: por um lado, aponta, como todos os verbos indicativos de acções ou comportamentos, uma tomada de interesse por algo, um proteger ou cuidar de um existente, um relacionar-se com ele, guardando-o, dando-lhe um sentido; por outro lado, é um ocultar ou esconder o existente mesmo por detrás do seu aspecto, sentido ou modalidade manifesta nesse comportar-se interessado/interesseiro?.

Assim, re-velar é também um velar, um comportamento ou cuidar, mas que tem como interesse o próprio interesse, é uma acção que deixa ser uma outra acção, tornando-a manifesta, declarando-a, repetindo-a, reiterando-a. Mas esta aquiescência, ou adesão, deixando ser ou manifestar um comportamento determinado, tem uma tripla face: em primeiro lugar, é uma acção que implica uma separação ou afastamento da acção ou comportamento que se manifesta, a libertação relativamente a ele, deixando-o ser na sua particularidade; seguidamente, a reiteração ou repetição do sentido ou modalidade revelados implica uma adesão ou um pôr-se fora, uma ex-posição e comprometimento dessa liberdade na modalidade descoberta, um reconhecimento da sua adequação à existên-

5 Das Wesen des Christentums, p. 1.

${ }^{6} \mathrm{~A}$ leitura que aqui oferecemos da revelação, ainda que baseada na obra de Feuerbach, procura compreender esse conceito com o auxílio das reflexões acerca da verdade conduzidas por Martin Heidegger em Vom Wesen der Wahrheit, de 1976 (edição bilingue alemão-português utilizada: Sobre a Essência da Verdade, tradução portuguesa de Carlos Morujão, Porto Editora, Porto, Portugal, 1995).

${ }^{7}$ Feuerbach refere-se a esta temática logo nas páginas iniciais da sua obra quando diz: '[...] as imagens da religião exprimem ao mesmo tempo pensamentos e coisas. '-Das Wesen des Christentums, p. 2. A imbricação de pensamento e coisa é o logos, simultaneamente coisa e coisa-dita, e imagem é eidos, o aspecto, o que aparece; noutros termos, o que a frase citada diz é que o que aparece é um significado determinado da coisa, uma sua modalidade existencial, e não apenas a coisa ela mesma ou um simples pensamento esvaziado e desligado da existência. 
cia do existente; em terceiro, e último lugar, esse acordo, adesão, reiteração ou aquiescência livres a uma modalidade do ser do existente só é possível com uma compreensão prévia da adequação desse comportamento à verdade da existência do existente, ou seja, a repetição ou adesão a um determinado aspecto, sentido ou modalidade da existência do existente implica um saber antecipado da significação da totalidade da existência desse mesmo existente.

A significação da palavra na língua alemã - aquela em que a obra foi escrita - não dista muito do seu sentido em português; contudo, a sua compreensão envolve um caminho distinto, se bem que paralelo, e aporta algumas orientações novas à interpretação do texto. A palavra revelação traduz o termo alemão Offenbarung, uma declaração, desocultamento ou manifestação que encerra uma disjunção, separação ou afastamento internos relativamente à coisa que se manifesta, ou revelado (outro sinónimo de Offenbarung é Entwicklung, que aponta para um desdobramento ou expansão de uma coisa num campo aberto). A raiz offen, constituinte da palavra Offenbarung, remete para um aberto descoberto, para uma espacialidade que permite que as coisas se manifestem tal como são no seu interior; esta abertura desocultante, livre de qualquer cobertura ou determinação, que possibilita o vir à presença ou desocultamento da coisa que aí se manifesta, ou revelado, separando-se dela, tem o nome de liberdade.

A separação interna ao acto livre que permite o desocultamento, o desvelamento do revelado, tem um duplo aspecto: por um lado, mostra o revelado como uma possibilidade entre outras que se colocam à distância diante da liberdade, possibilidade sobre a qual recai uma decisão e adesão livre, atestando a sua conformidade; por outro lado, o afastamento interno entre liberdade revelante que, reconhecendo a sua conformidade - que aqui tem o sentido de repetição ou adesão livre - à coisa revelada - o que é repetido - coloca a questão do fundamento dessa conformidade, ou seja, exige que o juízo de adequação entre ambos os termos seja sustentado por um terceiro termo, exterior a ambos, e esse termo constitui a sua verdade, ou $a$ verdade, simplesmente. O étimo bar, também ele componente da palavra Offenbarung, remete para esse horizonte, pois significa precisamente pureza, verdade. A abertura desocultante - porque permite que o revelado se manifeste - e questionante - porque pergunta pela verdade da sua relação de conformidade reconhecida a esse revelado - que constitui a liberdade é abertura não apenas e primitivamente ao revelado, mas ao que está para lá e acima dele, a verdade.

A liberdade é guarda e acolhimento do revelado, na medida em que este tem como horizonte referencial a verdade; a adesão ou posição de si da liberdade no que é revelado na imanência da sua actividade livre, numa modalidade existencial particular, tem como referência última um horizonte que surge, no interior dessa actividade imanente, como para lá e 
acima do resultado dessa actividade, ou seja, uma totalidade existencial que permanece para lá dos seus diferentes aspectos particulares, transcendendo-os. Assim, liberdade e verdade são indissociáveis, sendo a primeira condição da segunda e esta o horizonte de sentido de cada um dos actos de aqueloutra.

Surge agora a interrogação acerca do significado dessa referência à verdade. A palavra verdade em alemão diz-se Wahrheit, e tem como origem provável o verbo währen, que significa durar, continuar. Consequentemente, a decisão de adesão à existência revelada que caracteriza a liberdade tem como sentido último a grande questão da permanência, da duração para lá da transitoriedade e limitação do presente, em suma, a pergunta pela imortalidade e pelo sentido final e acabado da existência.

Possuímos, agora, os dados para podermos responder à questão bipartida que colocámos no início desta secção. A revelação não é um estado permanente ou historicamente determinável, mas sim um acontecimento caracterizado como doação ou gratuitidade: as acções livres mostram a sua relação primitiva e fundamental a uma plenitude de sentido que transcende a sua particularidade, uma relação de consonância e afinação entre liberdade e verdade que precede as relações particulares reveladas e que constitui o seu horizonte referencial ${ }^{8}$. Por outras palavras, a razão natural constitui a totalidade do ente, a verdade propriamente dita, a natureza; já a fé constitui-se como um coordenar de verdades particulares, manifestas sob condicionamento da projecção de algumas intenções, interesses e propósitos particulares, e da contenção, recolhimento ou apagamento de outros sentidos possíveis, a história. Em suma, sob fundo da verdade pura e simples, natural, a protenção - privilégios - e a retenção isenções - determinam os diversos aspectos particulares da existência, conferindo-lhes, após decisão livre - excepção -, um sentido determinado, histórico. Diz Feuerbach:

Por isso mesmo, mesmo na melhor das harmonias, existe entre ambas uma inevitável colisão, pois o carácter particular da fé e a universalidade da razão não se recobrem nem se satisfazem completamente, mas permanece um excedente de razão livre que, pelo menos em certos momentos, é sentido por si mesmo em contradição com a razão que se liga com a base da fé. ${ }^{9}$

8 É nesse sentido que vai a seguinte afirmação de Feuerbach: «A razão natural não é senão a razão universal, a razão com verdades e leis universais; pelo contrário, a razão cristã, é uma soma de verdades particulares, de privilégios e isenções particulares, é, portanto, uma razão particular. Dito de uma forma mais abreviada e incisiva: a razão é a regra, a fé a excepção à regra.»Das Wesen des Christentums, p. 3.

9 Das Wesen des Christentums, p. 3. 
E desta passagem ressaltam dois aspectos fundamentais: por um lado, percebemos que cada uma das verdades particulares oculta, pela consonância mesma que com ela mantém, a verdade propriamente dita; por outro lado, nenhum sentido particular esgota a totalidade de significações, permanecendo mesmo em aberto a possibilidade de erro ou contradição de alguns deles com a verdade, embora nela inclusos.

Deste modo, podemos afirmar que a revelação é o acontecimento primevo que deixa ser essa consonância originária, essa relação imediata e primitiva da totalidade da existência com a liberdade, totalidade essa que cai imediatamente ou se deixa ocultar por detrás do brilho do revelado, isto é, dos diversos aspectos particulares que dela participam. E esse acontecimento, que mostra como coisa-feita a consonância de liberdade e verdade, por intermédio da adesão ou entrega a um revelado particular ou fé - tem, por isso mesmo, um carácter fáctico:

[...] A diferença entre fé e razão torna-se mesmo num facto psicológico. ${ }^{10}$

O significado desta facticidade assenta no compromisso da liberdade, através da fé ou de-posição no revelado, de tomar a existência nas suas mãos, aceitando como património, regra ou verdade interior a essa existência mesma uma dimensão que lhe escapa, que se oculta atrás do revelado e com a qual se encontra em sintonia. A facticidade é o abandono da liberdade a uma situação que lhe chega de fora, a assunção da sua total responsabilidade pelo seu ser porque a sua acção é o fundamento de tal ser e, simultaneamente, o carácter totalmente injustificável - não fundado - de tal relação fundamental e possibilitante do aparecimento de coisas particulares. A facticidade é a indicação do ser que a liberdade deve ser para se tornar aquilo que ela é, na sua plenitude. A liberdade é para ser verdade, é para ser permanente, imortal, natural e a-histórica; a determinação do que esta permanência seja constitui o processo de auto-patenteamento ou auto-conhecimento desse ser, e por isso diz Feuerbach:

[...] O 'conhece-te a ti mesmo’ socrático [...] é o verdadeiro epigrama deste escrito...11

E revelação (Offenbarung) ou religião positiva são as palavras que denominam esta relação ou acontecimento originário que é a marca mesma de um ser que se encontra, desde logo, lançado no seu ser, ou melhor, cujo ser verdadeiro se dá como transcendência e do qual ele é responsá-

10 Das Wesen des Christentums, p. 3.

11 Das Wesen des Christentums, p. 6. 
vel, no sentido de a sua existência se abrir como uma enorme questão a que não se pode furtar de responder, mesmo sabendo que a resposta definitiva transcende as respostas particulares que vão sendo dadas a cada momento.

\section{Humanidade e religião - relação entre consciência e ser}

\section{A questão antropológica}

A análise do significado da revelação ou religião positiva mostrou-nos que a religião é a adesão ou fé num aspecto particular da existência, sob fundo de uma relação ou abertura livre à verdade ou totalidade dessa existência; vimos, também, como a religião se refere a um momento histórico, transitório, de uma totalidade natural e permanente. Assim, o fundamento da religião é essa diferença que se estabelece entre o particular historicamente determinado e o universal a-histórico ou natural. A religião encontra-se, deste modo, fundada na relação existente entre a parcialidade da existência que é objecto de fé enquanto actividade ou adesão livre e a totalidade a que essa modalidade existencial pertence e da qual participa. É isso mesmo que Feuerbach afirma quando diz:

A religião repousa na diferença essencial entre homem e animal - os animais não têm religião. ${ }^{12}$

Contudo, esta afirmação introduz um dado novo na questão: o protagonista da religião e, portanto, da relação entre particular e universal ou comum é o ser humano. Isto significa que, a cada momento, o homem histórico, particular e temporalmente determinado, se encontra lançado num projecto de realização de si que o mostra como limitado perante o horizonte da sua natureza humana, mas em relação íntima com a sua humanidade. Consequentemente, a pergunta pela diferença antropológica traduz a pergunta por um tipo de ser específico - o ser do humano - que possibilite uma viragem sobre si mesmo e a constituição da sua própria existência como problema; e o tipo de ser que responde a este requisito é, para Feuerbach, a consciência:

Mas qual é então esta diferença essencial entre o homem e o animal? A resposta mais simples e mais geral, e também a mais popular, a esta questão é a seguinte: a consciência; mas a consciência em sentido estrito, porque a consciência no sentido de sentimento de si, de faculdade de diferenciação sensível, de percepção das coisas exteriores

12 Das Wesen des Christentums, p. 9. 
segundo certos traços perceptíveis, tal consciência não pode ser recusada ao animal. Consciência em sentido estrito só existe quando um ser tem como objecto o seu género, a sua essencialidade (Wesenhaftigkeit). ${ }^{13}$

A marca da humanidade é a consciência; mas a determinação do modo como a humanidade se dá ao humano como horizonte de realização e como transcendência na imanência da sua vida de consciência implica uma análise do modo como Feuerbach concebe essa consciência. Desde logo percebemos que é um tipo de ser que deixa surgir diante de si, ou seja, deixa vir ao seu encontro enquanto obstáculo ou problema o seu ser mais próprio, a sua essencialidade ou género; isto significa que a consciência é um ser que não se identifica com o ser presente, mas que se caracteriza como um ser-para, como diferença e projecto de identificação futura, como exigência de contemporaneidade com o seu ser mais autêntico. Feuerbach refere-se a estes aspectos na seguinte passagem, quase com características silogísticas:

Onde existe consciência, existe capacidade para a ciência. A ciência é a consciência dos géneros. ${ }^{14}$

O sentido desta frase ficará mais claro se procedermos a algumas substituições que, de outro modo, permanecerão implícitas. Assim:

A consciência existe quando tem como objecto, como obstáculo e deixa vir à presença, a sua essencialidade ou ser mais próprio;

Onde existe consciência, existe a possibilidade da ciência;

A ciência identifica-se com a consciência da essencialidade ou ser mais próprio da consciência, isto é, ciência é a palavra que traduz o momento em que a essencialidade deixa de ser um obstáculo para a consciência, atingindo-se a concordância ou pacificação entre ambas, pura auto-referencialidade;

Por outras palavras, ter a sua essencialidade ou género como objecto e alcançar essa pacificação ou fruição permanente dos seus diversos estados a que se chama aqui ciência significa, para a consciência, ser consciência das diversas consciências, isto é, ser consciência de si;

Sendo esse o caso, então onde existe consciência existe a possibilidade da contemporaneidade com a consciência do seu ser mais próprio, ou seja, a existência da consciência implica a possibilidade da consciência de si enquanto possibilidade mais própria e horizonte de realização das consciências individuais.

13 Das Wesen des Christentums, p. 9.

14 Das Wesen des Christentums, p. 9. 
Noutros termos, existir, para a consciência, significa sempre existir enquanto consciência de algo, enquanto consciência de objecto, enquanto aquilo a que se costuma chamar de consciência intencional; isto indica que a consciência é pessoal, ou seja, é relação ao seu ser, dado enquanto objecto - a esse ser que ela, sendo intencional, necessariamente é -, relação que é livre, pois é dada como relação distanciada, como separação e união simultâneas ao ser que não é mais do que o conjunto das suas modalidades de doação ou dos seus sentidos possíveis - e não actuais - e, logo, como relação que comporta, a cada momento, uma decisão e uma escolha por um sentido determinado.

Mas, podemos perguntar-nos, de onde nos chega essa relação que envolve, em simultâneo, a liberdade da consciência - separação - e a necessidade - união - da sua relação a um ser que reconhece como seu? Se a liberdade se identifica com o movimento de distanciamento do ser ou totalidade de sentidos possíveis que caracteriza a consciência, de onde vem a necessidade que a liga a esse ser como a si mesma, denotando a sua pertença ao mesmo?

Ora bem, a necessidade surge devido ao facto de a consciência não ter apenas como possíveis as diversas modalidades do ser, sendo indiferente às mesmas, mas aspirar, em cada uma das consciências individuais, a ser consciência de consciência, isto é, consciência de si, como vimos. Consequentemente, a consciência, sendo liberdade, reconhece, enquanto possibilidade, uma outra liberdade, uma outra consciência que, por seu lado, é já relação livre ao ser na sua totalidade. Em suma, a consciência não se resume a um monólogo que encontra como interlocutor o próprio, mas um diálogo com um outro, uma alteridade à qual a consciência não pode ser indiferente, pois esta testemunha a sua pertença ao ser, ajuizando acerca das suas acções no campo partilhado de uma existência e atribuindo-lhe uma permanência que permite a sua identificação com os diversos momentos intencionais. A consciência é capaz de percepção, mas encerra também no seu interior a possibilidade de ser percebida ${ }^{15}$.

Dizer, como Feuerbach, que a consciência existente tem a capacidade para a ciência, implica que a existência da consciência é essencialmente uma aptidão, marcada pela liberdade, para compreender adequadamente uma outra consciência, um outro conjunto de sentidos possíveis, o dizer ou perceber que, sendo de um outro enquanto outra consciência, é também - sendo consciência - o seu, num movimento de resposta a esse dizer essencial, impedindo o seu esquecimento.

15 Diz Feuerbach: "O homem é para si ao mesmo tempo eu e tu; pode colocar-se no lugar do outro, precisamente porque tem como objecto, não apenas a sua individualidade, mas o seu género, a sua essência»-Das Wesen des Christentums, p. 10. 
Focando este aspecto, Feuerbach oferece-nos uma passagem esclarecedora quando diz:

O homem nada é sem objecto. Homens grandes, exemplares - esses homens que nos revelam a essência do homem - confirmaram este princípio com a sua vida. Tinham uma única paixão fundamental dominante: a realização daquele fim que era o objecto essencial da sua actividade. Mas o objecto ao qual o sujeito se refere essencial e necessariamente não é senão a essência própria, mas objectiva, desse sujeito. Se esse objecto é comum a vários indivíduos, iguais no género mas diferentes na espécie, então ele constitui, pelo menos enquanto é objecto desses indivíduos segundo a sua diversidade, a sua essência própria, mas objectiva. ${ }^{16}$

Conquanto a consciência seja intencional, consciência de um objecto particular, excluindo todos os outros, a sua finalidade essencial é o estabelecimento de uma relação com uma outra consciência, ou seja, ela não se esgota na percepção exclusiva do objecto individual, mas antes tem a objectualidade inclusiva ou totalidade referencial englobante de todos os sentidos ou consciências possíveis e é, por isso, finalidade ou horizonte das consciências intencionais individuais como seu modo próprio de ser; este movimento para chegar a um outro - outro que é, ele mesmo, consciência e, por isso, o sustentáculo da objectualidade inclusiva na medida em que percebe e suporta as diversas consciências individuais - é o factor que permanece nas distintas modalidades conscientes, garantindo-lhe uma coerência e estabilidade que de outro modo não seria alcançável, uma vez que o sujeito, protagonista da liberdade da consciência, se diluiria em cada um dos objectos individuais de que seria consciência ${ }^{17}$. A referência ou dialogia à consciência que, enquanto possível, suporta a totalidade de sentidos em cada uma das modalidades específicas da consciência garante ao sujeito uma permanência que de outro modo lhe seria negada, e é essa saída de si em busca do outro ou da objectualidade inclusiva transcendente suportada

16 Das Wesen des Christentums, p. 13.

17 A explicação que aqui damos da diferença entre consciência e consciência de si serve para afastar algumas dúvidas acerca da nossa leitura e do referente próprio dos termos imanência e transcendência. De facto, as referências de Feuerbach a uma vida interior e uma vida exterior - Das Wesen des Christentums, p. 10 -, identificando a primeira como vida em relação com o seu género, poderiam conduzir a uma falsa perspectivação do problema, invertendo os referentes de transcendência e imanência. Deste modo, sendo sempre consciência de objecto, ou seja, de uma transcendência, somente a consciência de si é verdadeiramente transcendente, pois o seu sentido não se esgota nas consciências particulares, mostrando-se, pelo contrário, como o seu inesgotável referencial de suporte. Do outro lado temos as consciências individuais, consciências cujo objecto não permanece transcendente, sendo o seu sentido último imanente à consciência de que são objecto e esgotando-se na identidade com esta última. 
por outra consciência que não a presente que é referida, na passagem citada, como objecto sem o qual o homem nada é.

Assim, a existência da consciência tem como finalidade testemunhar a essência humana, essência essa que se dá não apenas como ser ou existência, o que implicaria que estaria arbitrariamente à disposição das consciências ou liberdades individuais, que se teriam a si mesmas como referencial, mas como existência que, sendo própria, é, antes de mais, de um outro, pois essa totalidade de sentido é sua propriedade e é o seu dom, é uma permanência nesse outro fundada e por ele sustentada; o que cada consciência específica testemunha é a essência do humano enquanto tal, isto é, ela cuida para que a existência ou totalidade de sentido, sendo de uma outra consciência ou de um outro, dada como para lá das consciências particulares, como transcendência, não seja ignorada e caia no esquecimento.

Para concluir este ponto, resta-nos dizer que a essência do humano se dá, então, como sentido pleno da existência, sentido esse que provém de uma outra liberdade, de uma alteridade que sustenta, doa e transcende os diversos sentidos específicos das consciências particulares existentes, possibilitando assim a sua ligação vivencial e temporal. Compreender o que é a humanidade do humano é esclarecer o que é essa transcendência ou objectualidade inclusiva sustentada por um outro sujeito que surge na acção de distanciamento ou libertação das diferentes consciências individuais ou exclusivas - e de que forma ela se dá na imanência destas últimas.

\section{Religião e analítica da existência}

A existência da consciência tem como possibilidade mais própria aquilo a que Feuerbach chama ciência (Wissenschaft), um todo sistemático, orgânico e auto-referencial disposto de acordo com um único princípio de organização, simultaneamente origem e finalidade da consciência existente ${ }^{18}$. No parágrafo anterior concluímos que o princípio organizador desse todo sistemático era, também ele, uma consciência, mas uma consciência que se tem a si mesma como objecto, nas suas diversas modalidades individuais, que é consciência de si, e não apenas de objectos sensíveis.

Mas o que é que Feuerbach entende, concretamente, por consciência de si ou por consciência da essência do humano? O que é que a constitui e de que modo é que exerce a sua influência nos diversos aspectos particulares que dela participam? Quais são as condições que tornam possível o encontro de consciências que instaura essa relação simultânea de diversidade e identidade, essa relação de interdependência que faz a consciência de si depender da iniciativa das consciências individuais e estas encontrarem o seu sentido último na primeira?

18 Das Wesen des Christentums, p. 11. 
Tentaremos nas próximas linhas encontrar no texto feuerbachiano as respostas a essas questões.

\section{Religião e divindade - o ser da consciência como aí}

A religião em geral, enquanto idêntica à essência do homem, é idêntica à consciência de si do homem, à consciência que o homem tem da sua essência. Mas a religião é, numa expressão geral, consciência do infinito (unendlich); portanto, não é e não pode ser outra coisa senão a consciência que o homem tem da sua essência, a saber, de uma essência não finita, limitada, mas infinita. ${ }^{19}$

Feuerbach refere-se, nesta passagem, à religião em geral e à sua identidade com a essência do humano, ou melhor, com a consciência que o humano tem da sua essência. Em traços largos, esta utilização do qualificativo geral para caracterizar a religião ou a essência humana remete para uma dimensão comunitária do ser, para um ser partilhado ou para um ser-em-comum. É este ser-em-comum que Feuerbach denomina de unendlich, infinito; ora bem, o adjectivo unendlich tem o seu âmbito de significação relacionado com a noção de lugar, ou seja, aparece sempre referenciando uma certa espacialidade, uma certa abertura a um campo ou dimensão. Afirmar, como faz Feuerbach, que a religião é consciência de infinito significa que a religião, bem como a essência humana que com ela se identifica, é a marca de um tipo específico de entidade - o humano - cujo ser está à distância, cujo ser se abre num espaço comunitário de contornos específicos; dito noutros termos, a religião em geral, essa comunidade de ser ou de sentido partilhada pela humanidade sem excepção, ocorre numa consciência que, sendo sempre consciência de objecto, consciência de uma transcendência, tem o seu ser nessa transcendência mesma, isto é, o seu ser é situado, o seu ser é aí, à distância. A consciência, sendo na transcendência, é presença à distância ao seu próprio ser, é abertura que faz durar o seu ser. A ciência, atrás referida, é esta referencialidade do ser à consciência enquanto aquilo que o faz durar, na medida em que esta última permanece, enquanto abertura ou ponte ao ser dado numa transcendência, em afinidade íntima com esse mesmo ser.

Justifica-se, assim, a seguinte afirmação de Feuerbach:

Consciência limitada não é consciência; a consciência é, por essência, de natureza infinita. ${ }^{20}$

19 Das Wesen des Christentums, p. 10.

20 Das Wesen des Christentums, p. 10. 
Se a consciência propriamente dita é abertura ou relação ao ser, então as consciências individuais ou específicas - consciências de objectos particulares e não a objectualidade por si só - não podem ser mais do que a negação dessa auto-referencialidade entre consciência e ser, participando e estando a ela ligadas na exacta medida em que são o seu negativo, o seu não-ser. A finitude é o não-ser da consciência. Contudo, cada uma destas consciências individuais, ou modalidades do ser - pois carregam a marca do ser, embora não se identifiquem com ele, permanecendo parcelares - tem como possibilidade mais própria a ciência, como vimos. Isto significa que um encontro entre consciências continua sendo possível e que a determinação interna ou destinação da consciência propriamente dita é a infinitude, a abertura e a permanência, o que vem reiterar a pertinência da questão que colocámos anteriormente acerca das condições desse encontro originário que cumpre a finalidade da consciência e, consequentemente, realiza a essência do humano.

Feuerbach foca esta questão quando diz, referindo-se à essência da religião, que:

Na relação com os objectos sensíveis, a consciência do objecto pode ser certamente distinguida da consciência de si, mas no caso do objecto religioso a consciência coincide imediatamente com a consciência de si. ${ }^{21}$

Ou seja, no caso do objecto religioso - isto é, no caso da consciência que é abertura ao ser, à transcendência, consciência de si ou ser-aí ${ }^{22}$ ocorre uma simultaneidade de acontecimentos, o surgimento concordante e harmónico de duas consciências, um encontro entre a consciência individualmente tomada e a consciência de si ou, se quisermos, entre consciência específica e consciência genérica. Por outras palavras, na religião dá-se - como já havíamos visto quando nos debruçámos sobre o significado da revelação - esse acontecimento primordial de encontro de consciências, ou seja, acontece a justaposição entre existência da consciência e a sua essência. A nossa utilização da palavra justaposição não sucede aqui sem motivo, uma vez que o que aqui se dá é um juízo, uma tomada de posição acerca de uma posição dada, uma aposição, no sentido em que se estabelece uma relação de agregação ou adjunção entre as duas consciências que são o fundamento e o suporte dessa relação instaurada.

21 Das Wesen des Christentums, p. 22.

22 Cf. Das Wesen des Christentums, p. 22, a passagem seguinte: "O objecto sensível está fora do homem, o objecto religioso está nele, é mesmo um objecto intrínseco (wesentlich) - é, portanto, um objecto que o abandona tão pouco quanto a sua consciência de si, a sua consciência moral o abandona -, um objecto íntimo, e mesmo o mais íntimo, o mais próximo de todos.» (o parêntesis é nosso). O objecto religioso é a consciência de si, é esse objecto essencial (wesentlich) que não abandona o humano. 
A referência da consciência individual à consciência de si, ou a sua adjunção a esta, tem como efeito retroactivo a individuação da última, ou seja, a consciência de si deixa de configurar um modo de ser anónimo estranho à consciência individual para se constituir numa existência protagonizada e que importa ao seu protagonista, pois é o seu ser, e não um ser indiferente, que está aí em jogo:

O objecto sensível é em si indiferente, independente da convicção, da faculdade de julgar, mas o objecto da religião é um objecto eleito: é o ser preferido, primeiro, supremo; pressupõe essencialmente um juízo crítico, a diferença entre o divino e o não-divino, entre o que é e o que não é digno de adoração. ${ }^{23}$

Esta tomada de posição, ou juízo crítico, implica uma decisão fundada num convencimento íntimo, baseada numa antecipação ou disposição - um colocar-se para lá de si mesmo - do sentido autêntico do ser da consciência, antecipação essa respeitante à diferença entre o ser verdadeiro ou duradouro - divino - e o ser falso ou efémero - não-divino -, o que conduz Feuerbach a declarar:

O objecto do sujeito não é outra coisa senão a essência objectivada do próprio sujeito. [...] A consciência de Deus é a consciência de si do homem, o conhecimento de Deus o conhecimento de si do homem. ${ }^{24}$

Determinados que estão o sentido da religião e o domínio de significação das referências feuerbachianas à divindade, resta-nos clarificar os termos envolvidos nesse encontro do humano existente com o humano essencial; pretendemos, assim, clarificar a doação essencial como transcendência na imanência da existência humana por intermédio de uma analítica do modo humano de ser, identificado por Feuerbach, de uma forma muito particular, com a religião.

\section{O entendimento ou a pré-compreensão existencial}

A religião é a cisão do homem consigo: ele põe Deus face a si como um ser que lhe é oposto. Deus não é o que o homem é - o homem não é o que Deus é. ${ }^{25}$

A cisão operada no interior do ser humano, do ser do humano, resulta numa posição ou projecção, num lançar para fora de si o seu próprio

23 Das Wesen des Christentums, p. 22.

24 Das Wesen des Christentums, p. 22.

25 Das Wesen des Christentums, p. 41. 
ser, o que nos permite qualificar a religião como consciência não-tética ou não-posicional de si do homem, isto é, como uma modalidade da consciência que, tendo o seu próprio ser diante de si, como objecto pois, como vimos, a marca mesma da consciência é ter o seu ser numa transcendência ou ser-aí - desconhece que esse ser é o seu, não se reconhecendo nele; este modo da consciência é não-posicional porque, embora o ser em causa seja o seu, o ser do humano, e seja por ela posto fora de si, a consciência relaciona-se com ele como se essa exteriorização de si não tivesse ocorrido, não reconhecendo a sua humanidade nele; assim, a relação instaurada entre consciência e ser é a separação, ou seja, acontece a cisão e a segregação de um nada separatório, mantendo o seu ser à distância como se de um ser diferente se tratasse:

Deus e homem são extremos: Deus é o absolutamente positivo, a soma de todas as realidades, o homem o absolutamente negativo, a soma de todas as nulidades. ${ }^{26}$

Ou seja, a essência - uma das traduções possíveis para a palavra Inbegriff, vertida aqui para o português como soma - de Deus é, na perspectiva deste elemento do ser do humano, a realidade, o existente, e a essência do homem apenas a exclusão ou a capacidade de se constituir como excepção a essa positividade absoluta, como um nada que a ela se opõe. Consequentemente, Deus ou a consciência de si aparece como pura positividade, como pura actividade oposta à consciência. Mas como podemos interpretar esta oposição?

A resposta a esta questão surge como a resultante de uma dupla perspectiva acerca da oposição: em primeiro lugar, toda a oposição se concretiza como um qualquer tipo de resistência ou obstáculo a superar; assim, neste caso específico, essa resistência toma a forma de uma situação que, estando diante da consciência, vem contra esta, vem ao seu encontro. Em segundo lugar, toda a oposição é, de algum modo, uma forma de contradição; consequentemente, a oposição é, também, um dizer ou um exprimir colocado diante e dirigindo-se ao encontro da consciência.

Disto resulta que a actividade ou ser que a consciência tem diante de si toma a forma de uma situação dada em toda a sua positividade e, portanto, como facto, mas uma situação de contornos específicos, pois concretiza-se não como uma sucessão desconexa e sem relação entre si de objectos, mas como um conjunto ou soma concatenada num todo referencial de relações em acto; isto é, a questão do ser do humano, que neste elemento se coloca sob a forma de uma certo adiantamento de si a si mesmo, ainda que não reconhecido e perspectivado sob o modo da indife-

26 Das Wesen des Christentums, p. 41. 
rença, remete para uma resposta que se situa a um nível outro que o da mera coisificação desse mesmo ser. A pergunta pelo ser do humano, cuja resposta é antecipada aqui sob a forma de uma pré-compreensão existencial, é uma pergunta pelo sentido desse ser, e daí a doação desta totalidade de relações em acto como seu horizonte ou sentido antecipado. A este todo referencial, resposta antecipada à questão colocada ao ser do humano ele mesmo através da sua cisão interna, chama Feuerbach inteligência ou entendimento (Verstand $)^{27}$.

E é este entendimento que o homem tem da sua essência ou ser próprio, embora marcado pela ausência da sua consciência, que é lançado diante de si como seu termo, antecipando o que essa essência possa ser e, desse modo, constituindo uma compreensão prévia do seu ser. Enquanto totalidade que o ser humano projecta diante de si sem disso ter conhecimento, o entendimento aparece ou manifesta-se como pura auto-actividade, como auto-posição regida por uma finalidade interna cuja única relação com as existências individuais é a abstracção, uma vez que permanece inexoravelmente delas separado por um nada que é, na perspectiva que abordamos neste ponto, a própria consciência. Diz Feuerbach:

O entendimento é em nós a essência neutral, apática, incorruptível, que não se deixa cegar - a luz pura e sem emoções da inteligência. [...] É a fonte da identidade lógica, a consciência da lei, da necessidade, da regra, da medida, porque ele próprio é actividade segundo leis, é a necessidade da natureza das coisas como auto-actividade, a regra das regras, a medida absoluta, a medida das medidas. ${ }^{28}$

Ou seja, é pura relacionalidade, pura formalidade legal sem atenção ao conteúdo que é objecto da lei; o entendimento é actividade mediadora auto-referencial, isto é, no extremo das relações que instaura encontra-se sempre a si mesmo, sem lugar para a diferença, configurando, assim, um ser em acto que é de todos - pois é universal - e não é de ninguém, é um ser anónimo e impessoal. Assim, enquanto identidade lógica, meramente formal, este entendimento, este $\mathrm{A}=\mathrm{A}$ manifesta-se como aquilo que permanece no fundo de cada uma das diferentes relações, isto é, constitui-se como o poder ou faculdade genérica, como um ser generalizado e indiferenciado que dura, que medeia e, assim, sustenta as relações particulares:

A essência do entendimento, tal como ela devém objecto para o homem no interior da religião, é Deus como essência universal, impessoal, abstracta, isto é, metafísica. [...] Mas esta essência não tem para a religião mais significado do que tem para uma ciência par-

27 Cf. Das Wesen des Christentums, p. 42.

28 Das Wesen des Christentums, p. 42-43. 
ticular um princípio universal do qual ela parte. É somente o ponto de apoio e o ponto de ligação supremo e derradeiro, como que o ponto matemático da religião. ${ }^{29}$

Enquanto ponto matemático da religião, o ser do entendimento é a manifestação daquilo que, por um lado, já se sabe à partida como verdadeiro - é uma pré-compreensão lançada diante de si do ser do humano - e que, por outro, se constitui como momento de suspensão do juízo no qual acontece o compromisso que institui uma relação de legalidade ou de mediação entre o plano da universalidade ou genérico do ser e o seu plano vivencial ou específico. Por outras palavras, o entendimento constitui-se como horizonte de sentido, como uma duração ou uma escorrência sem dimensões concretas que se abre e serve de elemento mediador constante de uma consciência que assiste a esse fluir, que é presença ao seu próprio actuar - ainda que não reconhecido - diferenciado nas diversas relações ligadas num todo de sentido.

A presença da consciência ao ser, aqui sob o modo da exclusão ou libertação desse ser, deve ser compreendida como o surgimento mesmo da dimensão da temporalidade, uma vez que o seu movimento interno de cisão instaura uma actividade a ela exterior, com uma finalidade própria, a que a consciência escapa e que, por sua vez, lhe escapa e a que esta assiste; adiantando-se a si mesma e tendo como obstáculo ou problema o seu próprio ser - ainda que numa modalidade que implica o desconhecimento dessa relação essencial -, a consciência adia e, portanto, remete para um tempo futuro a sua realização, enquanto horizonte ou sentido final de possibilidade efectivo e permanente do cumprimento do seu ser próprio, entretanto já dado numa compreensão existencial prévia.

Contudo, a demora neste desconhecimento acerca do seu ser que caracteriza esta dimensão genérica e englobante da consciência, a dimensão futurante do entendimento, suspendendo o juízo e, logo, adiando ad aeternum - e remetendo a sua realização efectiva para um além que é a eternidade ou permanência que se abre à consciência precisamente como seu contrário, como natureza - a reconciliação com o seu ser autêntico, numa espécie de dúvida metódica, porque constantemente retomada, acerca do sentido deste ser, implica o mergulho da consciência e a sua anulação nesse todo que vem ao seu encontro, não se concretizando e sendo engolida no fluxo temporal permanente. É porque permanece nas teias da indecisão, da irresolução e da arbitrariedade descomprometida com o ser que a consciência se perde no ser, é um nada desse ser que é devorado pela actividade auto-referencial e universal do todo ${ }^{30}$. O entendimento é

29 Das Wesen des Christentums, p. 43-44.

${ }^{30}$ Cf. Das Wesen des Christentums, p. 44. 
apenas a expressão de um ser que é posto diante do humano, um ser que se torna um objecto indiferente, objecto este que não possibilita a descoberta do seu modo de ser próprio, daquele que é o traço da sua humanidade, identificando-o com os restantes elementos da natureza enquanto tal.

Assim, há que encontrar uma dimensão do ser na qual o humano se envolva de tal modo que esteja, aí, em causa o seu próprio ser, a sua humanidade mesma, o que nos reenvia para a próxima dimensão do ser do humano a analisar, uma dimensão marcada pela culpa e pelo desejo de uma presença efectiva a um Deus pessoal.

\section{O pecado e a sua significação para a consciência}

De acordo com Feuerbach, a religião, enquanto abertura ao ser, tem o seu fundamento, como vimos, numa cisão que ocorre no interior do humano, cisão ou devir dois esse que o separa do ser enquanto tal por um nada que dele se abstrai. Contudo, a constatação do ser que ocorre nesse movimento abstrainte - que pode ser resumida num 'É!' ou num 'Há!' eternamente repetido, sem diferença - nada acrescenta à religião perspectivada enquanto idêntica à essência humana, pois a comprovação do ser por si só não mostra de que modo esse ser anónimo e igualizante poderá interessar ao humano, que tem a abertura ou relação à sua determinação ou destinação autêntica e mais própria como diferença antropológica mesma. Compreende-se, assim, que Feuerbach afirme o seguinte:

É sem dúvida do interesse da religião que a essência que ela toma como objecto seja diferente do homem; mas é também do seu interesse, e até mais, que esta outra essência seja ao mesmo tempo humana. Que uma outra essência exista, isso só diz respeito à existência, mas que seja uma essência humana diz respeito à sua essencialidade intrínseca. ${ }^{31}$

Dito de outro modo, a participação ou interesse da religião, enquanto abertura ou relação do humano com o seu ser verdadeiro ou autêntico, implica uma cisão, uma duplicidade interna ao próprio humano que é a base da diferença antropológica. Ora bem, o interesse que aqui é referido significa, antes de mais, um inter-esse, ou seja, como um ser que é termo médio entre os elementos de uma relação, como um ser participado e partilhado pelas partes que nele intervêm, no caso concreto, os humanos.

$\mathrm{O}$ entendimento mostra-nos a existência que se abre à nossa frente enquanto problema ou obstáculo, de tal forma que, ao mesmo tempo que dela nos abstraímos, também a fazemos surgir e somos, por isso, dela responsáveis; isto significa que a tomamos nas nossas mãos e que somos

31 Das Wesen des Christentums, p. 44. 
obrigados a responder ao seu apelo. No entanto, tomar algo nas nossas mão ou tomar interesse por algo implica um tomar interesse pela própria existência, pois interessar-se é reconhecer o ser que se abre como uma dimensão de partilha, comunicação e participação e, como tal, como elemento mediador de uma relação que se estabelece e que reconhece um outro com o qual partilhamos essa existência e que nos requisita do lado de lá. Cuidar da existência é, primeiro que tudo, cuidar da sua própria existência, enquanto espaço de mediação que permite estabelecer uma relação com a sua essencialidade, com a verdade do seu ser ou, como vimos algumas páginas atrás, com aquilo que faz durar ou permanecer o ser humano. Mas como se estabelece essa relação e qual o seu significado ao nível da consciência, o que é o mesmo que dizer ao nível do ser do humano? Para Feuerbach:

Na religião, o homem quer satisfazer-se em Deus. Mas como poderia encontrar nele consolo e paz, se ele fosse um ser essencialmente diferente? Como posso partilhar da paz de um ser, se não faço parte da sua essência? Se a sua essência é diferente, também a sua paz é essencialmente diferente, não é paz para mim. Como posso participar da sua paz, se não posso partilhar da sua essência, mas como pode a sua essência ser partilhada se eu for de facto um ser diferente? Tudo o que vive só sente paz na sua própria essência, no seu próprio elemento. Por isso, se o homem sente paz em Deus, só a sente porque Deus é a sua verdadeira essência, porque só nela ele está próximo de si, porque tudo no qual até aí procurava paz e tomava como sua essência, era uma essência diferente, estranha. Se o homem deve e quer satisfazer-se em Deus, tem de encontrar-se em Deus. ${ }^{32}$

A satisfação do humano em Deus mais não é do que a sua realização, o seu cumprimento nele, ou seja, é na tranquilidade, no repouso em Deus - na medida em que esse repouso implica um deixar-ser da sua essência mesma - que o humano cumpre a sua destinação íntima, que preenche a totalidade das suas aspirações. Assim, aquilo que é objectivado no momento da bipartição interna ao humano é não só o seu ser tomado como objecto puro e simples e, nessa medida, como um ser indiferente e anónimo, mas o ser enquanto também ele ser de um sujeito humano:

O entendimento é um ser universal, panteísta, é o amor pelo universo, mas a religião, particularmente a cristã, um ser inteiramente antropoteísta, o amor do homem por si mesmo, a auto-afirmação exclusiva da essência humana, e da essência subjectivamente humana. ${ }^{33}$

32 Das Wesen des Christentums, p. 45.

33 Das Wesen des Christentums, p. 46. 
O movimento de separação interno ao humano projecta diante de si a questão do sentido do ser; no entanto, projecta essa questão não de modo objectivo, indiferente, mas de tal forma que se encontra a ela intimamente ligado, pois é do seu ser que se trata. Isto acontece porque o que é projectado são as sua aspirações, os seus anseios, tornados diferentes porque transformados numa totalidade fundada numa outra consciência, num outro sujeito; é isto que Feuerbach indica ao referir a essência subjectivamente humana, isto é, uma essência ou ser que tem um protagonista, que tem um sujeito, e um sujeito humano.

Mas como se dá essa humanidade, essa subjectividade a uma consciência que a projecta diante de si e que a ela é presença? Ela dá-se, de acordo com Feuerbach, como auto-afirmação exclusiva da essência humana. Isto significa que, tal como no entendimento, o ser é lançado diante do humano como uma totalidade de relações auto-referencial, como sentido pleno e permanente da existência, mas agora de tal forma que o movimento de exclusão tem a sua origem no próprio ser, isto é, esse ser devindo sujeito exclui o humano particular, aquele que dele se cindiu, do seu interior, exclui-o do ser-em-comum. Dito de forma mais clara, a essência humana, posta como auto-actividade, como um todo concatenado de relações tem como seu fundamento um sujeito ou uma consciência que não é já a consciência particular que se cindiu do todo e que responde ao apelo pelo sentido do ser de forma arbitrária e desligada, mas uma consciência que, estando em sintonia com a totalidade de relações que constitui o ser, o seu ser, está em conformidade com o seu sentido último, em harmonia com ele.

É esta consciência em afinação com o ser que é projectada diante da consciência que se separa, e que não só mostra o cumprimento da sua finalidade como possível, mas também manifesta à consciência cindida a sua culpa pela separação. Atentemos sobre o seguinte exemplo: confrontados com a possibilidade de realizar ou não determinada acção, um crime, por exemplo, colocando-nos à distância do ser e ponderando acerca dos resultados de uma tal intervenção, duas perspectivas são possíveis, de acordo com o que vem sendo dito. Do ponto de vista do entendimento, podemos cometer o crime sem consequência, pois ninguém nos observa e a nossa intervenção no ser não nos compromete com ele, ou seja, esse sentido parcial que damos à existência não nos afecta em nada, podemos sempre retirar-nos e começar de novo sem passado, sem memória. Já do ponto de vista que aqui discutimos, e que podemos adiantar ser o da vontade, a nossa intervenção no ser tem uma testemunha que nos compromete com a nossa acção, que fixa as nossas acções e que nos identifica com elas. As nossas acções são rupturas com o sentido pleno da existência, sentido esse que está em plena sintonia com essa consciência que testemunha os nossos comportamentos e que nos compromete com eles, mos- 
trando-nos que a sintonia com o ser é possível e está ao nosso alcance. Somos, assim, tornados objecto de um juízo exterior que nos liga às nossas acções passadas e que testemunha a ruptura com aquela que é a nossa natureza, a nossa essência.

Consequentemente, a temporalidade, que é a marca da relação da consciência ao ser, não tem apenas um dimensão futura e liberta de qualquer responsabilidade. $\mathrm{O}$ futuro que se abre à consciência como seu horizonte de sentido e lugar de exercício da sua liberdade tem, também, um passado, isto é, uma dimensão pela qual a consciência é responsável e que a assombra e determina na sua realização. A consciência é cisão relativamente ao ser, é libertação, mas é, também, responsabilidade perante um ser que é o seu e cujo sentido último está já dado. É nessa medida que Feuerbach afirma:

Deus é objecto da religião como ser moralmente perfeito. Deus só habita um coração puro, só é acessível ao sentimento puro. Mas porquê, se ele mesmo não é o ser moral puro? O pecado é uma contradição com a essência divina - na linguagem da religião, que tudo personifica: Deus odeia o pecado, é contra ele. Porque é então o pecado uma contradição com a essência divina? Porque constitui a natureza do homem? Porque reside na sua essência? Claro que não! Se, por natureza, o homem agisse no pecado, então agia como devia agir, então o seu pecado seria um comme il faut, uma harmonia e não uma dissonância no universo. Portanto, o pecado só contradiz a essência divina porque contradiz a essência humana, aquilo que o homem é e pode ser. ${ }^{34}$

Pecado é a palavra que denomina a relação de compromisso da consciência com um ser que é o seu. O pecado é a separação, a falta relativamente à sua própria existência, um crime contra si mesmo, pois a cisão com o seu ser é um esquecimento de si, um condenar-se ao perecimento por vias de um esquecimento da verdade ou da permanência possível da sua essência, da sua destinação autêntica. A perfeição moral de Deus é idêntica à consciência de si, ao acordo do humano consigo mesmo; cindir-se desse acordo é estar em contradição, é ter diante de si como objecto, como problema o seu próprio dizer, as suas próprias acções como se se tratasse das acções de um outro, um estranhamento de si que deve e pode ser superado visando o cumprimento da sua essência.

$\mathrm{O}$ ódio de Deus pelo pecado configura uma presença ou consciência que se exclui da relação com a consciência que se cindiu, devido a essa cisão mesma, enquanto atentado à sua existência:

34 Das Wesen des Christentums, p. 47. 
A contradição do pecado com Deus é, por isso, apenas uma contradição do homem individual com a sua essência. ${ }^{35}$

O pecado ocorre como individualização da consciência, como particularização do seu carácter intrinsecamente intencional ou objectual, ou seja, o humano, ou a consciência que o caracteriza enquanto diferença antropológica, individualiza-se e separa-se da consciência propriamente dita, projectando sob fundo do sentido comum ou partilhado um sentido particular, acontecendo uma desafinação ou contradição relativamente à totalidade instaurada e, assim, relativamente a si mesmo enquanto autor ainda que desconhecendo essa autoria - dessa posição de si. A desafinação resultante desta acção individuante surge como um impedimento, como um obstáculo à tranquilidade, à satisfação, à serenidade ou ao deixar-ser prometidos pela essência, e o ódio de Deus pelo pecado traduz a auto-exclusão do humano da sua finalidade já dada e entretanto esquecida, instalando-se o sentimento de culpa ou de falta como sinal dessa separação. Assim:

$\mathrm{Na}$ medida em que o homem religioso opõe a si a sua essência como essência absolutamente santa, ele sente-se tal como é e tem consciência de si, em contradição com aquela essência, como não sendo adequado àquela exigência, àquela lei, sem poder igualá-la, como imperfeito, como pecador. $\mathrm{O}$ homem está cindido da sua própria essência: não é como deve ser e, por consequência, como pode ser, e neste conflito sente-se infeliz, nulo, condenado, tanto mais quanto na religião a lei moral não é para ele objecto enquanto lei e como sua essência própria e verdadeira, mas como objecto de uma outra essência pessoal que odeia os pecadores, que os exclui da sua graça, da fonte de toda a salvação e felicidade. ${ }^{36}$

Por outras palavras, este ódio de outra essência pessoal aos pecadores, este furtar-se à relação com eles, mostra à consciência que se cinde da sua essência que ela o habita, que tem uma opacidade e uma natureza essencial, mas que é incapaz de a tornar objecto para si, de o conhecer; o seu próprio ser surge-lhe como objecto para uma outra consciência, como ser para outrem, isto é, o seu ser tem o seu fundamento num outro, e o sentimento da sua queda ou separação relativamente à sua natureza, à sua essência, é a atestação do seu carácter pessoal. A consciência cindida capta o seu ser enquanto ele não é para si, na medida em que lhe escapa por princípio e, no entanto, é-o, sente-o como seu mesmo sem o conhecer. Diz Feuerbach:

35 Das Wesen des Christentums, p. 47.

36 Das Wesen des Christentums, p. 48. 
A consciência da perfeição moral é desprovida de coração, porque é a consciência da minha nulidade pessoal, e da nulidade mais sensível de todas - a nulidade moral. ${ }^{37}$

Sendo sempre consciência intencional, ou seja, consciência de objecto, a consciência visa ter como objecto o seu próprio ser, ser que é ele mesmo consciência de objecto. Contudo, existe sempre um descentramento ou uma diferença entre o seu que, sendo seu, sendo também consciência, lhe aparece agora como objecto e o ser que ela, enquanto consciência, é nesse preciso momento, isto é, entre o ser conhecido e o ser vivido. É esse desfasamento ou dissonância que se instala como uma sombra na consciência pessoal e que a impede de se relacionar com o seu próprio ser, enquanto conservar a exigência de o ter como um ser para si, como objecto diferente de si. Assim, visar o seu próprio ser enquanto objecto é sempre visá-lo não na medida em que é para a consciência presente, mas enquanto ser para uma consciência já passada, enquanto ser para um outro sujeito ou uma outra liberdade que, como tal, é à distância e, portanto, se furta a uma captação coagulante, restritiva dessa liberdade em acto. Consequentemente, a perfeição moral, ou seja, a sintonia entre a consciência e o seu ser é mostrada à consciência pessoal, enquanto consciência que visa conhecer o seu ser, mantendo-se dele distanciada, como prova - no sentido de experiência de si ao nível do sentir - da sua incapacidade de, dessa forma, se adequar à sua própria essência. Consequentemente:

Eu não posso ter consciência da perfeição moral, sem ter ao mesmo tempo consciência dela como uma lei para mim, pois a consciência moral não é, no fundo, senão a consciência daquilo que eu devo ser. A perfeição moral não depende, pelo menos para a consciência moral, da natureza, mas da vontade; ela é uma perfeição da vontade, a vontade perfeita. Não posso pensar nem representar a vontade perfeita, a vontade que coincide com a lei, que é ela mesma a lei, sem pensar ao mesmo tempo como objecto da vontade, isto é, como dever-ser para mim. Em suma, a representação do ser moralmente perfeito não é uma representação apenas teórica, pacífica, mas é ao mesmo tempo uma representação prática, que convida à acção, à emulação, que me lança a mim mesmo em tensão, na diferença e no conflito comigo mesmo, porque ao evocar em mim o que eu devo ser, diz-me ao mesmo tempo na cara, sem qualquer lisonja, o que eu não sou. $^{38}$

Surpreendemos, assim, uma dupla temporalização da consciência: enquanto memória, passado ou consciência de um ser que já foi e que não

37 Das Wesen des Christentums, p. 48.

38 Das Wesen des Christentums, p. 48-49. 
é mais, o tempo individualiza, torna a consciência pessoal, mas também integra, pois antecipa e pressente, desejando-o - através da vontade -, um ser partilhado, um ser-em-comum aos diversos objectos - manifestos na actividade da consciência -, objectos esses que surgem não numa mera sucessão, mas interiormente coordenados num todo de sentido; enquanto futuro, é a promessa da realização possível dessa integralidade pela acção, pela emulação, pela prática. Assim, a vontade, através do desejo de um estado anterior que escapa à consciência como consciência de objecto particular, mostra ao humano uma relação de ser - e não de conhecer - com um ser, a sua humanidade, que, sendo possível, ainda não se efectivou e que se encontra adiada, remetida para um porvir às mãos e da responsabilidade do humano que, tendo a sua humanidade como objecto, se individualiza e reconhece a sua pertença pela consciência do seu carácter pecador, pelo sentimento da sua separação violadora da harmonia do ser.

\section{A humanidade do homem}

Mas como superar esta contradição, este conflito de si consigo? Para Feuerbach, esta situação de conflitualidade só é superável através da consciência do amor, ou seja, pela superação da exigência da presença a si enquanto objecto do conhecer, como objecto visível diante da consciência, transmutando-se numa presença a si, ou ao ser, enquanto sentimento, enquanto intuição, enquanto compreensão da sua humanidade possível, enquanto penetração nessa humanidade pelo sentimento:

A intuição, a consciência do amor divino ou, o que é o mesmo, Deus como um ser ele mesmo humano - esta intuição é o segredo da incarnação. A incarnação não é senão a efectiva manifestação sensível da natureza humana de Deus. ${ }^{39}$

A intuição da humanidade de Deus é o segredo da incarnação, segredo que se manifesta através da sensibilidade, isto é, de um sentir que é um sentir-se, de um sentir comum às sensações individuais. A utilização da palavra segredo (Geheimnis) por Feuerbach neste contexto indica que o autor se refere a um ethos, a um habitar o ser - Heim significa casa, lar -, a um estar nele como em sua casa, da consciência e, logo, do humano. O segredo da incarnação é um habitar íntimo, dissimulado, oculto, que não é objecto para a consciência, pelo menos objecto particular a ela contraposto. Assim, o amor é esse habitar a humanidade, é sentimento de situação como sentimento de presença, é estar presente nesse espaço vital

39 Das Wesen des Christentums, p. 51. 
- vivido e não conhecido - como em sua casa, compreender todas as coisas, e a si mesmo, como parte de um todo relacional. E a incarnação (Menschwerdung), esse devir-humano de Deus, é a concretização sentida, vivida, da relação entre consciência e consciência de si, entre o humano e o seu ser; é a compreensão do humano como existente na existência, como presença permanente no conjunto das suas acções, contemplando-as, entregando-se a elas. Por essa razão Feuerbach afirma:

Um rei que não traz no coração o bem-estar dos seus súbditos, que, sentado no seu trono, não se encontra em espírito nas suas casas, que não é na sua disposição de espírito - como diz o povo - um homem comum, um tal rei também não se erguerá fisicamente do seu trono para agraciar os súbditos com a sua presença pessoal. Não se elevou o súbdito até ao rei antes de o rei ter descido até ao súbdito? E quando o súbdito se sente honrado e agraciado com a presença pessoal do seu rei, refere-se esse sentimento apenas à aparição visível como tal, ou não se referirá antes à aparição da disposição de espírito, à essência filantrópica que é motivo dessa aparição? ${ }^{40}$

As consciências particulares submetem-se, sujeitam-se, concatenam-se sob o governo de uma só consciência apenas porque, na sua essência, elas são já concatenação, relação. A objectualidade da consciência não é, na verdade, uma objectualidade exclusiva, como vimos no ponto que discutimos acima; o ser da consciência não é a exclusão de si diante dos objectos, o pôr-se fora da relação, mas a relacionalidade ela mesma, essa disposição ou sentido projectado, antecipado que não se esgota nas consciências individuais. A consciência é relação e só nessa medida pode ser relação de relações, ou seja, é necessária uma consciência individual, ou um ser humano, para que surja a carência de uma consciência de Humanidade; apenas porque cada consciência, cada ser humano individual projecta e antecipa como sua possibilidade a Humanidade, o ser relação, pode ser depois nela incluído. E a Humanidade não é mais do que sentido projectado, do que uma entrega de si a uma situação, abrindo-se a essa situação e, com essa abertura, colocar a questão do sentido do seu ser, isto é, a questão respeitante à coerência interna da sua existência, mas com a salvaguarda da manutenção da sua diferença enquanto indivíduo, diferença essa que só acontece na relação que se estabelece entre um eu que se faz tu e um tu que se faz eu, ou seja, num ser em devir, num ser em relação. Por essa razão, Feuerbach faz a seguinte afirmação:

Isto é explicado pela doutrina da Igreja como não sendo a primeira pessoa da divindade que incarna, mas a segunda - foi a segunda pes-

40 Das Wesen des Christentums, p. 51. 
soa que criou o mundo, ela é o Deus que fala ao homem, que representa o homem em e perante Deus, em suma, não é senão o Deus humano - a segunda pessoa que, na verdade, como se irá mostrar, é o Deus propriamente dito, a pessoa verdadeira, a primeira pessoa da religião. Sem este terminus medius, que é todavia o terminus a quo da incarnação, a incarnação parece inconcebível, misteriosa, 'especulativa', enquanto que, em conexão com ele, é a sua consequência óbvia. ${ }^{41}$

A segunda pessoa, o Verbo incarnado, a relação protagonizada é quem fala ao humano, é a mediação entre o humano e a Humanidade. Mas esse termo médio não é apenas um momento a ser superado com vista a uma finalidade superior, ele é também essa finalidade, a Humanidade propriamente dita. Dito de outro modo, o que caracteriza a consciência enquanto diferença antropológica é a própria dialogia, é a própria capacidade ou possibilidade de estabelecer um diálogo de si consigo, do humano com a sua Humanidade. Um pouco à imagem da eudaimonia aristotélica, que era um termo médio extremado, pois era fundamento, mediação e finalidade em simultâneo, também a religião, enquanto modo próprio do ser do humano, é essa relacionalidade ou dialogia com o outro de si, concentrada num só, dada como anterioridade e, simultaneamente, como possibilidade efectivada. Ou seja, como facto, como coisa-feita:

A incarnação, o segredo do Deus-homem, não é, pois, uma misteriosa composição de opostos, não é um facto sintético, como é considerado pela filosofia especulativa da religião, porque sente uma alegria especial pela contradição; é um facto analítico - uma palavra humana com sentido humano. ${ }^{42}$

E é esta facticidade do humano, já referida anteriormente neste texto, que descreve o encontro entre consciências, o diálogo directo entre o $\mathrm{eu}$ e o tu que caracteriza a religião, ou seja, o modo humano de se relacionar com a sua Humanidade.

Assim, o encontro de consciências é isso mesmo, um encontrar-se já sendo, mas um encontrar-se com uma determinação ontológica, como um ente aberto compreensivamente a si, aberto a si mesmo pela compreensão da verdade da sua existência: é uma satisfação, um sentimento de coisa feita que traduz o culminar de uma demanda motivada por uma abertura ao ser, por uma carência interna, uma necessidade ou indigência do ser do humano; mas esta é uma miséria que repousa na Humanidade do humano, na sua essência ou ser mais próprio e que descobre como terminus dessa indagação pelo seu ser, como seu fundamento, a sua própria Humanidade.

41 Das Wesen des Christentums, p. 52-53.

42 Das Wesen des Christentums, p. 58. 
E este sentir e compreender, esta anterioridade e posteridade não remetem para uma dimensão processual, mas fáctica, pois são contemporâneos e elementos estruturais do ser do humano. Para terminar a análise:

Quando Deus é o amor - mas o conteúdo essencial deste amor é o homem - não é o amor de Deus pelo homem o fundamento e o centro da religião, não é o amor do homem para consigo mesmo, objectivado e intuído como a suprema verdade objectiva, como a essência suprema do homem? ?3 $^{43}$

\section{Conclusão}

Resta-nos, agora, em jeito de conclusão e para suspender este movimento elíptico em torno do mesmo, retomar as palavras iniciais acerca da transcendência e da imanência. Alguns poderão objectar que essa distinção não tem qualquer lugar ou sentido no pensamento feuerbachiano, agora que Feuerbach mostrou a integração possível do indivíduo humano com a sua Humanidade, através da individuação desta e da humanização daquele na relação amorosa. Assim, não seria já pertinente falar de transcendência - e, por implicação, de imanência - uma vez que:

O ponto central da teoria da incarnação, o místico «homem-Deus», é o amor de Deus pelo homem: na medida em que Deus ama o homem, em que Deus pensa o homem, em que se preocupa com o homem, já é homem; ao amar, Deus renuncia já à sua divindade, desapropria-se de si, antropomorfiza-se. A verdadeira incarnação é o argumento espiritual ad hominem desta humanidade intrínseca e essencial de Deus. ${ }^{44}$

Ou seja, Deus e humano estão ligados de forma tão íntima, tão próxima como um só corpo relacional existente que o extravasa, o transcende. Contudo, é o próprio Feuerbach que pode dirigir-se a esta objecção e afastá-la definitivamente quando diz, logo no prefácio de Das Wesen des Christentum:

Quando eu, por exemplo, acerca da crença no pecado original, nada mais afirmo senão que o homem não é por natureza tal como deve ser, apenas lhe ponho na boca uma verdade inteiramente universal, racionalista, uma verdade que cada homem sabe, e mesmo o rude homem natural ainda comprova quando cobre a sua nudez com uma simples pele. Pois o que afirma ele com essa cobertura, senão que o indivíduo humano não é por natureza aquilo que deve ser? É certo que na base

43 Das Wesen des Christentums, p. 60.

44 Das Wesen des Christentums, p. 53. 
do pecado original se encontra esta ideia universal, mas aquilo que o torna num objecto de fé, numa verdade religiosa, é justamente o particular, o diferente, o que não é coincidente com a razão. ${ }^{45}$

E, algumas páginas depois:

$\mathrm{O}$ autor tem, contudo, de solicitar ao leitor benevolente, mas sobretudo ao mais adverso, que não deixe de ter em conta que, ao escrever acerca de tempos antigos, não está a escrever no tempo antigo, mas no e para o tempo novo, portanto, que ao observar a sua essência primitiva, não perde de vista o fantasma moderno, que o conteúdo deste escrito é, de facto, patológico ou fisiológico, mas o seu objectivo é ao mesmo tempo terapêutico ou prático. ${ }^{46}$

Consequentemente, a diferença entre o que o ser humano é e o que deve ser, essa diferença interna que abre para uma dimensão futura dimensão essa que é a sua própria Humanidade - e para a esperança enquanto presença possível à verdade do seu ser persiste como seu traço fundamental, como diferença antropológica mesma, não se dilui neste encontro do indivíduo com a sua Humanidade descrito no amor, pois este permanece numa dimensão de possibilidade real, de possibilidade de presença a um acontecimento primitivo, ao alcance do humano, como um ainda-não da sua Humanidade; no entanto, esta não é uma relação entre indivíduos e Humanidade em geral, é uma relação de cada humano particular com a sua Humanidade, tal como é configurada pela religião, com a promessa da salvação ou reconciliação particular. Assim, é o próprio ser-aí, a espacialidade relacional de cada um dos seres humanos o próprio encontrar-se enquanto facticidade, do indivíduo em relação originária com a sua Humanidade que se abre como a questão fundamental acerca da verdade do seu ser. E é esse ser-aí que, dando-se como sentido do ser daquele indivíduo particular, mas um sentido que ele partilha com outros nessa espacialidade comum, embora do seu ponto de vista, que se dá como transcendência, como lei do ser, uma lei que chega de fora.

A descrição do ser-aí conduzida por Feuerbach corresponde à descrição desse pathos humano, do padecimento comum a todos, mas com contornos específicos para cada um; no entanto, o que está realmente em causa é o trabalho de o habitar, de se relacionar com ele, de o acolher e de o compreender, na medida em que, embora proveniente de uma transcendência, de um aí, esse ser é o de cada um, objecto de uma eleição imemorial e, por isso, somos responsáveis por ele. Em suma, o trabalho aqui é o de uma descrição do ser do humano, mas tendo como horizonte uma ética.

45 Das Wesen des Christentums, p. 3.

46 Das Wesen des Christentums, p. 6. 
Enquanto sentimento da adesão do ser humano à sua Humanidade, esse sentimento do homem-Deus, a religião permanece uma lei da transcendência, uma lei permanente para o humano, tornada distinta dele, exigência de uma alteridade que se projecta como horizonte de sentido das suas acções. Por isso, diz Feuerbach:

Não é, pois, a proposição «Deus ama o homem» um orientalismo - a religião é essencialmente oriental - mas que na nossa língua significa: o mais elevado é o amor do homem? ${ }^{47}$

Vinda de um passado imemorial, a religião enquanto mandamento de uma alteridade que requisita a presença do indivíduo, que solicita a sua resposta adequada, é sentimento orientador das acções individuais, sentimento sublime da verdade, da perfeição e do cumprimento pleno do próprio ser, através da relação a uma transcendência que, ela só, é garante e fundamento, enquanto pólo referencial, de uma identidade ética possível. E essa relacionalidade acontece, sem dúvida, como relação a uma transcendência na imanência da vida humana de consciência.

\section{Bibliografia}

Ferry, Luc, Qu'est-ce qu'une vie réussie?, Éditions Grasset \& Fasquelle, Paris, 2002.

Feuerbach, Ludwig, Spiritualismo e materialismo, trad. Ferrucui Andolfi, Editori Laterza, Bari, 1993.

Feuerbach, Ludwig, Das Wesen des Christentums, trad. portuguesa de Adriana Veríssimo Serrão, Fundação Calouste Gulbenkian, Lisboa, 1994.

Feuerbach, Ludwig, Etica e Felicità - con una raccolta di aforismi di argomento morale, trad. Barbara Bacchi, Edizioni Guerini e Associati, Milano, 1997.

Heidegger, Martin, Vom Wesen der Wahrheit, edição bilingue alemão-português de Carlos Morujão, Porto Editora, Porto, 1995.

Vários, Pensar Feuerbach - Colóquio comemorativo dos 150 anos da publicação de "A Essência do Cristianismo» (1841-1991), org. J. Barata-Moura e V. Soromenho Marques, Edições Colibri, Lisboa, 1993.

Vários, O homem integral - Antropologia e Utopia em Ludwig Feuerbach, coord. Adriana Veríssimo Serrão, Centro de Filosofia da Faculdade de Letras da Universidade de Lisboa, Lisboa, 2001.

47 Das Wesen des Christentums, p. 60. 


\begin{abstract}
Individualism is one of the fundamental traits of our time, based on an emphatic and recurrent defence of individual freedom, as experienced by consciousness. This point of view seems to entail a refuse of all kinds of transcendence, cosmological or onto-theological, characterized by an authoritarian and undisputed heteronomy. However, this perspective does not take into account a third type of transcendence, one that occurs in that radical immanence, in the core of individual freedom and autonomy. This type of transcendence takes shape as an ethical and aesthetical relationship carved in the heart of each individual human being, each one of his particular conscious states and the simultaneous consciousness of his Humanity. The aim of this essay is to give an understanding of Ludwig Feuerbach's The Essence of Christianity and its philosophy of Revelation, as a reflection on religion and its anthropological origins. In our viewpoint, The Essence of Christianity is an effort to ascertain the genetic elements of human religiosity and clarify its meaning as a movement of reconnecting the human individual with a transcendence that is his own Humanity, given in the immanence of his conscious life. Religion remains a law of transcendence, as the feeling that binds the individual to his Humanity, an everlasting commandment coming from an Otherness that projects itself as a horizon to his free actions.
\end{abstract}

